\title{
Effect of Corticotropin-Releasing Hormone Antagonist on Oestrogen- Dependent Glucoprivic Suppression of Luteinizing Hormone Secretion in Female Rats
}

\author{
S. Tsukahara, H. Tsukamura, D. L. Foster* and K.-I. Maeda \\ School of Agricultural Sciences, Nagoya University, Nagoya 464-0814, Japan. \\ *Reproductive Sciences Program, Departments of Obstetrics and Gynecology and Biology, University of Michigan, Ann Arbor, \\ Michigan 48109-0404, USA.
}

Key words: corticotropin-releasing hormone, luteinizing hormone, 2-deoxyglucose, oestrogen, glucose availability.

\begin{abstract}
Pharmacological reduction of glucose availability with 2-deoxyglucose (2DG) suppresses pulsatile luteinizing hormone (LH) secretion in rats and growth-retarded lambs. Gonadal steroids enhance the glucoprivic suppression of $\mathrm{LH}$ secretion in rats. The present study determined if corticotropinreleasing hormone $(\mathrm{CRH})$ plays a role in mediating oestrogen-dependent and -independent glucoprivic suppression of LH secretion. The study was conducted in ovariectomized (OVX) rats some of which received Silastic implants containing oestradiol-17 $\beta\left(\mathrm{OE}_{2}\right)$ dissolved in peanut oil at $20 \mu \mathrm{g} / \mathrm{ml}$ to produce a physiological plasma level of $\mathrm{OE}_{2}(30 \mathrm{pg} / \mathrm{ml})$. Seven days after ovariectomy, the rats were stereotaxically implanted with a guide cannula into the third cerebral ventricle. Seven days later, blood samples were collected through an indwelling atrial cannula every 6 min for $3 \mathrm{~h}$ for LH pulse determination. After the first hour of blood sampling, a $\mathrm{CRH}$ antagonist, [D-Phe ${ }^{12}$, $\mathrm{Nle}^{21,38}$ hCRF-(21-41), or vehicle was injected into the third cerebral ventricle through the implanted cannula before 2DG administration through the indwelling atrial cannula. Pulsatile LH secretion was suppressed by $2 \mathrm{DG}\left(200 \mathrm{mg} / \mathrm{kg}\right.$ b.w.) in the vehicle-treated rats bearing $\mathrm{OE}_{2}$ implants. The $\mathrm{CRH}$ antagonist $\left(5.65 \mathrm{nmol}\right.$ ) blocked the suppressive effect of 2DG on pulsatile $\mathrm{LH}$ secretion in the $\mathrm{OE}_{2}{ }^{-}$ treated OVX animals. On the other hand, in the absence of oestrogen, the effect of a twice greater dose of 2DG $(400 \mathrm{mg} / \mathrm{kg}$ b.w.) was not blocked by five times greater amount of $\mathrm{CRH}$ antagonist $(28.3 \mathrm{nmol})$. These results suggest the mechanisms mediating glucoprivic suppression of $\mathrm{LH}$ secretion involve two components: one is oestrogen-dependent and the other oestrogenindependent. $\mathrm{CRH}$ may be involved in the oestrogen-dependent component of glucoprivic suppression of LH secretion but not the oestrogen-independent one.
\end{abstract}

The reduction of glucose availability is considered as one of the factors suppressing LH secretion under nutritional stress. Pharmacological reduction of glucose availability with 2-deoxyglucose (2DG) interrupts oestrous cyclicity in Syrian hamsters (1), and suppresses pulsatile luteinizing hormone $(\mathrm{LH})$ secretion in lambs (2) and rats (3-5). Our previous study in female rats suggested that fasting activates the catecholaminergic input from the solitary tract nucleus to the paraventricular nucleus (PVN) to stimulate corticotropinreleasing hormone $(\mathrm{CRH})$ release and then suppress gonadotropin-releasing hormone/LH secretion (6). It is thought that noradrenergic input to the PVN suppresses LH secretion through a CRH-dependent pathway in the presence of oestrogen or through a CRH-independent pathway in the absence of this steroid. This is because local noradrenaline injection into the PVN suppresses LH secretion through stimulating $\mathrm{CRH}$ release in oestradiol-17 $\beta\left(\mathrm{OE}_{2}\right)$-primed ovariectomized (OVX) rats, but it causes a transient suppression that is not mediated by CRH in OVX animals (7). Accordingly, we propose that fasting stress suppresses $\mathrm{LH}$ secretion in a CRHdependent/oestrogen-dependent manner and a CRHindependent/oestrogen-independent manner.

Correspondence to: Kei-ichiro Maeda, School of Agricultural Sciences, Nagoya University, Chikusa, Nagoya 464-0814, Japan (e-mail: keimaeda@agr.nagoya-u.ac.jp). 


\section{Glucoprivic suppression of luteinizing hormone}

Glucose availability is sensed by a glucose sensitive area in the lower brain stem, such as the area postrema and the information is sent to the PVN via the noradrenergic pathway. The existence of this pathway, which may be similar to that mediating fasting-induced suppression of $\mathrm{LH}$ secretion, is based on the following evidence: central administration of 2DG suppresses pulsatile LH secretion in rats (3) and lambs (2); lesions of the area postrema, a circumventricular organ in the caudal brain stem, prevent the effect of $2 \mathrm{DG}$ on normal oestrous cyclicity in Syrian hamsters (8); glucoprivation stimulates noradrenaline release in the PVN; and the blockade of catecholamine synthesis in the PVN nullifies the glucoprivic suppression of LH secretion (5). In addition, 2DG suppresses $\mathrm{LH}$ secretion in the presence or absence of sex steroids in both genders, with steroid-treated animals being more sensitive to the glucoprivation (4). In this regard, glucoprivic suppression of LH secretion may be mediated by a CRHdependent and/or CRH-independent mechanism.

The present study was designed to determine whether CRH mediates the oestrogen-dependent or oestrogen-independent $2 \mathrm{DG}$ effect on pulsatile $\mathrm{LH}$ secretion in female rats.

\section{Results}

Figure 1A shows the representative profiles of plasma LH levels in $\mathrm{OE}_{2}$-treated $\mathrm{OVX}$ individuals, which were injected with CRH antagonist $(5.65 \mathrm{nmol})$ or vehicle into the third cerebral ventricle before $2 \mathrm{DG}$ administration at the dose of $200 \mathrm{mg} / \mathrm{kg}$ b.w. In the vehicle-treated animals, 2DG transiently suppressed pulsatile LH secretion. In contrast, pulsatile LH secretion was not blocked by $2 \mathrm{DG}$ treatment when the animals received an intracerebroventricular (i.c.v.) injection of the $\mathrm{CRH}$ antagonist. There was significant $(\mathrm{P}<0.05)$ difference in the percent change in mean plasma LH concentration before and after 2DG treatment between the vehicleand CRH antagonist-injected groups (Mann-Whitney $U$ test, Fig. 1B).

Figure 2A shows representative profiles of plasma LH levels in the OVX individuals treated with $2 \mathrm{DG}$ ( $400 \mathrm{mg} / \mathrm{kg} \mathrm{b.w.)}$ after i.c.v. injection of a $\mathrm{CRH}$ antagonist $(28.3 \mathrm{nmol})$ or vehicle. Pulsatile $\mathrm{LH}$ secretion was suppressed by $2 \mathrm{DG}$ in both vehicle-injected and $\mathrm{CRH}$ antagonist-injected groups. Pretreatment of animals with the $\mathrm{CRH}$ antagonist at $28.3 \mathrm{nmol}$ did not affect the 2DG-induced suppression of $\mathrm{LH}$ pulses. There was no significant difference in the percent change in mean plasma LH concentration between the groups (Mann-Whitney $U$-test, Fig. 2B).

\section{Discussion}

Our previous study revealed that oestrogen enhances the $2 \mathrm{DG}$ effect to inhibit pulsatile LH secretion, because 2DG
(A)

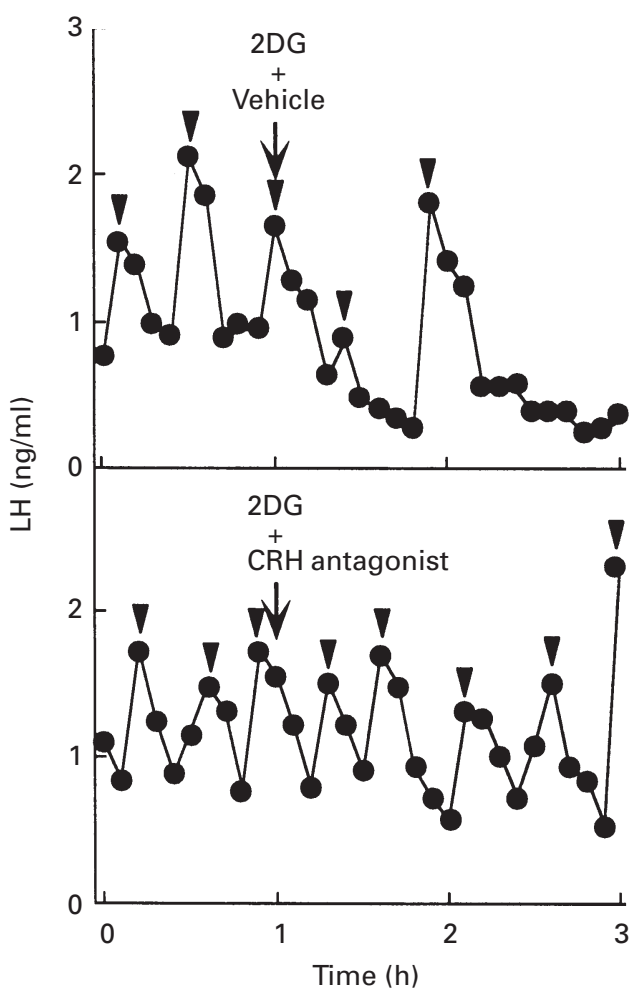

(B)

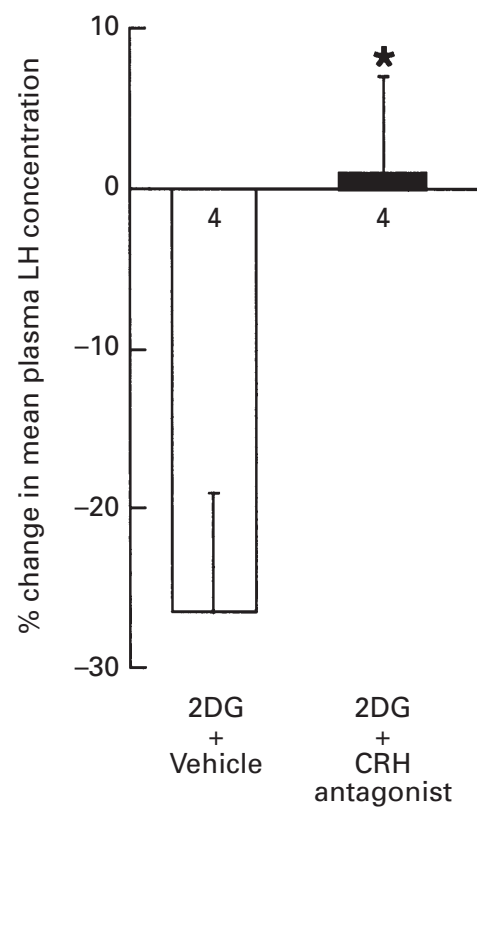

FIG. 1. (A) Representative profiles of plasma LH concentrations in $\mathrm{OE}_{2}$-primed OVX rats. CRH antagonist (5.65 nmol) or vehicle was injected into the third cerebral ventricle before the intravenous injection of $2 \mathrm{DG}(200 \mathrm{mg} / \mathrm{kg} \mathrm{b.w.)}$ at arrows. Blood samples were collected every $6 \mathrm{~min}$ for $3 \mathrm{~h}$. Arrowheads indicate peaks of LH pulses determined by PULSAR computer program. (в) Per cent change in mean plasma LH concentrations before and after $2 \mathrm{DG}$ treatment in $\mathrm{OE}_{2}$-primed OVX rats. Values are the mean \pm SEM. Numbers in columns indicate the number of animals used in each group. ${ }^{*} \mathrm{P}<0.05$ ( $v s$ vehicle-injected group). 
(A) OVX

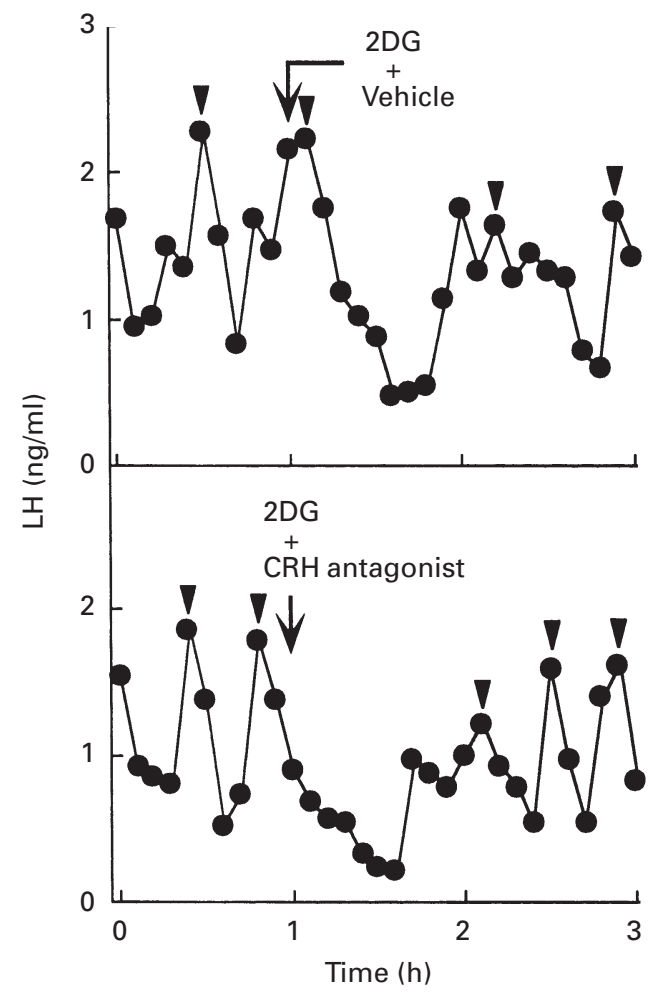

(B)

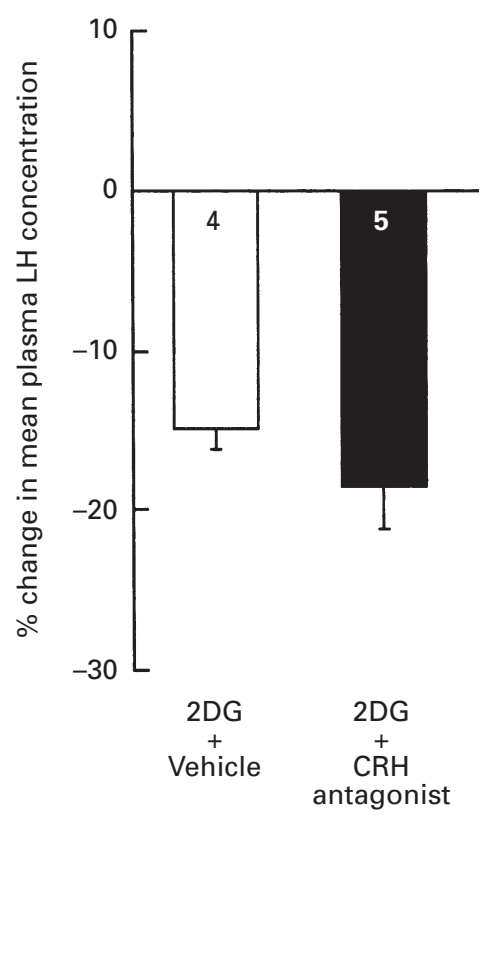

FIG. 2. (A) Representative profiles of plasma LH concentrations in OVX rats, which were injected with CRH antagonist (28.3 nmol) or vehicle before $2 \mathrm{DG}(400 \mathrm{mg} / \mathrm{kg}$ b.w.) treatment at arrows. Arrowheads indicate peaks of LH pulses. (B) Per cent change in mean plasma LH concentrations before and after 2DG treatment in OVX rats. Numbers in columns indicate the number of animals used in each group. See Fig. 1 for details.

suppresses LH secretion at $200 \mathrm{mg} / \mathrm{kg}$ b.w. in steroid-treated rats, but not in females without steroid treatment (4). In the present study, therefore, the minimum doses of 2DG were chosen to induce suppression of LH secretion in both OVX and $\mathrm{OE}_{2}$-treated OVX animals according to the abovementioned result. The CRH antagonist at the larger dose $(28.3 \mathrm{nmol})$ was ineffective in preventing the glucoprivic suppression of LH release in OVX animals. This dose of the antagonist in OVX rats was five times as much as that was used in $\mathrm{OE}_{2}$-primed $\mathrm{OVX}$ rats in the present study. It is reported that $\left[\mathrm{D}-\mathrm{Phe}^{12}, \mathrm{Nle}^{21,38}\right]$ hCRF-(21-41) used in the present study is approximately 15 times more potent than that of $\alpha$-helical CRF-(9-41) in terms of antagonizing corticotropin release (9). $\alpha$-Helical CRF-(9-41) at $26 \mathrm{nmol}$ i.c.v. injection into the third cerebral ventricle was effective in preventing the suppression of $\mathrm{LH}$ release in rats that had fasted for $48 \mathrm{~h}$ (6). Therefore, the doses of 2DG and CRHantagonist chosen in the present study are based on the previous experiments and seem to be within reasonable ranges to evaluate their effect.

In the present study, 2DG suppressed LH secretion in both $\mathrm{OVX}$ and $\mathrm{OE}_{2}$-treated $\mathrm{OVX}$ rats, but this effect was blocked by the $\mathrm{CRH}$ antagonist at a lower dose in $\mathrm{OE}_{2}$-treated $\mathrm{OVX}$ animals. This raises the possibility that reduced glucose availability suppresses $\mathrm{LH}$ secretion through stimulating $\mathrm{CRH}$ release in the presence of oestrogen, but through another pathway in the absence of oestrogen. Several lines of evidence indicate that oestrogen is involved in activating $\mathrm{CRH}$ production or release in the PVN, since the primary transcript for $\mathrm{CRH}$ was increased by endotoxin lipopolysaccharide and $c$-fos mRNA was increased in CRH-immunoreactive cells on the morning of pro-oestrus in female rats (10). Both corticotropin release and corticosterone release in response to restraint stress were greater in pro-oestrus compared with other phases of oestrous cycle and these responses were also higher in $\mathrm{OE}_{2}$-treated $\mathrm{OVX}$ rats than $\mathrm{OVX}$ rats (11). Taken together, the increased sensitivity to 2DG in the presence of oestrogen might be due to the activation of $\mathrm{CRH}$ production or release by oestrogen. On the other hand, the 2DG may not stimulate $\mathrm{CRH}$ to the level sufficient to suppress LH secretion in the absence of oestrogen and, therefore, the higher amount of 2DG could suppress LH secretion through a pathway other than $\mathrm{CRH}$ release. Another possibility is that opioidergic system mediating $\mathrm{CRH}$ action may be modulated by oestrogen, since the suppressive effect of $\mathrm{CRH}$ on $\mathrm{LH}$ secretion is mediated through opioidergic system $(12,13)$ and naloxone-induced LH secretion is dependent upon the presence of gonadal steroids in rats $(14,15)$.

Arginine vasopressin (AVP) has been reported to mediate suppressive effects of stress on LH secretion (16), and to play a role in compensation for the CRH deficiency (17). In addition, AVP and CRH synergistically stimulate corticotropin release from the isolated perfused anterior pituitary 


\section{Glucoprivic suppression of luteinizing hormone}

cells (18). In this context, AVP may have a co-operative function with $\mathrm{CRH}$ or even an alternative function to $\mathrm{CRH}$ in oestrogen-independent glucoprivic suppression of LH.

These results suggest the mechanisms mediating glucoprivic suppression of $\mathrm{LH}$ secretion involve two components: one is oestrogen-dependent and the other oestrogen-independent. CRH may be involved in the oestrogen-dependent component of glucoprivic suppression of LH secretion but not the oestrogen-independent one.

\section{Materials and methods}

\section{Animals}

Adult female Wistar-Imamichi strain rats weighing $230-275 \mathrm{~g}$ were used Animals were kept in a light ( $14 \mathrm{~h}$ light: $10 \mathrm{~h}$ dark, lights on at $0500 \mathrm{~h}$ )- and temperature $\left(22 \pm 2{ }^{\circ} \mathrm{C}\right)$-controlled room with free access to water and food (Labo-MR-stock, Nihon Nosan Kogyo Co., Yokohama, Japan).

Animals showing at least two consecutive oestrous cycles were bilaterally OVX. Some animals were implanted with Silastic tubing (inner diameter, $1.5 \mathrm{~mm}$; outer diameter, $3.0 \mathrm{~mm}$; length, $25 \mathrm{~mm}$; Dow Corning, Midland, MI, USA) containing $\mathrm{OE}_{2}$ (Sigma Chemical Co., St. Louis, MO, USA) dissolved in peanut oil at $20 \mu \mathrm{g} / \mathrm{ml}$ immediately after ovariectomy to produce physiological plasma $\mathrm{OE}_{2}$ levels (19).

\section{Brain surgery}

One week after the ovariectomy, a stainless steel guide cannula (22 gauge; Plastic Products Co., Roanoke, VA, USA) was stereotaxically implanted into the third cerebral ventricle. Stereotaxic coordinates of the tip of i.c.v. cannula was $0.8 \mathrm{~mm}$ caudal and $7.0 \mathrm{~mm}$ ventral to the bregma at the midline according to a rat brain atlas (20). Animals were allowed to recover from brain surgery for 1 week before blood sampling.

\section{Drugs}

2DG (Sigma) was dissolved with saline at the concentration of 250 or $125 \mu \mathrm{g} / \mu \mathrm{l}$ for administration to $\mathrm{OVX}(400 \mathrm{mg} / \mathrm{kg}$ b.w. $2 \mathrm{DG})$ or $\mathrm{OE}_{2}$-primed OVX (200 mg/kg b.w. 2DG) animals, respectively. The 2DG doses chosen for each group in the present study are the minimum effective doses to suppress LH secretion according to our previous study (4). The CRH antagonist [D-Phe ${ }^{12}, \mathrm{Nle}^{21,38}$ ] hCRF-(21-41); (Salk Institute, La Jolla, CA, USA) was used for the present study. The CRH antagonist was dissolved in $10 \mu \mathrm{l}$ of $0.01 \% \mathrm{~L}$-ascorbic acid for i.c.v. injection to the OVX $(28.3 \mathrm{nmol}$ antagonist) or $\mathrm{OE}_{2}$-primed $\mathrm{OVX}(5.65 \mathrm{nmol}$ antagonist) rats, respectively. All reagents were prepared immediately before use.

\section{Experimental protocol}

One day before blood sampling, a silicone cannula (inner diameter, $0.5 \mathrm{~mm}$; outer diameter, $1 \mathrm{~mm}$; Shin-Etsu Polymer Co., Tokyo, Japan) was inserted into the right atrium through the right jugular vein. Blood samples $(100 \mu \mathrm{l})$ were taken from the freely-moving animals every $6 \min$ for $3 \mathrm{~h}$. An equivalent volume of rat red blood cells taken from donor animals was suspended in saline and replaced through the cannula after each blood sampling.

The CRH antagonist or vehicle was infused into the third cerebral ventricle through an inner cannula (28 gauge; Plastic Products Co, Roanoke, VA, USA) inserted into the guide cannula with a microsyringe at $2.5 \mu \mathrm{l} / \mathrm{min}$ for $4 \mathrm{~min}$ before the $2 \mathrm{DG}$ injection. Four hundred $\mu \mathrm{l}$ of $2 \mathrm{DG}$ solution were administered through the atrial catheter after the first hour of blood sampling. Blood samples were centrifuged at 12,000 r.p.m. for $10 \mathrm{~min}$, and plasma was kept at $-30^{\circ} \mathrm{C}$ until assayed for $\mathrm{LH}$.

\section{Hormone assay}

Plasma LH concentrations were determined by a double antibody RIA with a rat LH RIA kit provided by the National Hormone and Pituitary Program (Baltimore, MD, USA) and results were expressed in terms of the reference preparation NIDDK rat LH RP-3. The least detectable level of LH was $0.156 \mathrm{ng} / \mathrm{ml}$ for $50 \mu \mathrm{l}$ of plasma. The intra- and interassay coefficients of variation were $6.71 \%$ at level of $0.76 \mathrm{ng} / \mathrm{ml}$ and $11.2 \%$ at level of $1.26 \mathrm{ng} / \mathrm{ml}$, respectively.

\section{Statistical analysis}

LH pulses were identified by the PULSAR computer program (21). The criteria for LH pulse detection have been previously described (22). Per cent changes in mean plasma LH concentration before and after 2DG treatment were determined by calculating the ratio of the difference in mean plasma LH concentrations between the pre- and post-2DG treatment periods to the mean LH concentration before $2 \mathrm{DG}$ treatment in individual animals. Statistical differences of the percent change in mean plasma LH concentration between vehicle- and $\mathrm{CRH}$ antagonist-injected groups were analysed by the Mann-Whitney $U$-test.

\section{Acknowledgements}

We are grateful to the National Hormone and Pituitary Program for the LH assay kit, the Imamichi Institute for Animal Reproduction for supplying the animals, Dr W. Vale for providing the CRH antagonist, Drs G. R. Merriam and K. W. Wachter for the PULSAR computer program, and Y. Niwa for her technical assistance. The RIA and LH pulse analysis were performed at the Nagoya University Radioisotope Centre and the Nagoya University Computer Centre, respectively. This work was supported in part by Grantsin-Aid (nos 08660342 and 10460131) to H. T. and K. M.; a Grant-in-Aid for International Scientific Research (Joint Research No. 09044215) to K. M.; a Research Fellowship of the Japan Society for the Promotion of Science for Young Scientists (no. 80003249) to S. T. from the Ministry of Education, Science, Sports and Culture, Japan; and the U.S-Japan Cooperative Science Program to D. L. F. and K. M. from NSF and JSPS.

\section{Accepted 17 August 1998}

\section{References}

1 Schneider JE, Friedenson DG, Hall AJ, Wade GN. Glucoprivation induces anestrus while lipoprivation may induce hibernation in Syrian hamsters. Am J Physiol 1993; 264: R573-R577.

2 Bucholtz DC, Vidwans NM, Herbosa CG, Schillo KK, Foster DL. Metabolic interfaces between growth and reproduction. V. Pulsatile luteinizing hormone secretion is dependent on glucose availability. Endocrinology 1996; 137: 601-607.

3 Murahashi K, Bucholtz DC, Nagatani S, Tsukahara S, Tsukamura H, Foster DL, Maeda K-I. Suppression of luteinizing hormone pulses by restriction of glucose availability is mediated by sensors in the brain stem. Endocrinology 1996; 137: 1171-1176.

4 Nagatani S, Bucholtz DC, Murahashi K, Estacio MAC, Tsukamura H, Foster DL, Maeda K-I. Reduction of glucose availability suppresses pulsatile luteinizing hormone release in female and male rats. Endocrinology 1996; 137: 1166-1170.

5 Nagatani S, Tsukamura H, Murahashi K, Bucholtz DC, Foster DL, Maeda K-I. Paraventricular norepinephrine release mediates glucoprivic suppression of pulsatile luteinizing hormone secretion. Endocrinology 1996; 137: 3183-3186.

6 Maeda K-I, Cagampang FRA, Coen CW, Tsukamura H. Involvement of the catecholaminergic input to the paraventricular nucleus and of corticotropin-releasing hormone in the fasting-induced suppression of luteinizing hormone release in female rats. Endocrinology 1994; 134: 1718-1722.

7 Tsukamura H, Nagatani S, Cagampang FRA, Kawakami S, Maeda K-I. Corticotropin-releasing hormone mediates suppression of pulsatile luteinizing hormone secretion induced by activation of $\alpha$-adrenergic receptors in the paraventricular nucleus in female rats. Endocrinology 1994; 134: 1460-1466.

8 Schneider JE, Zhu Y. Caudal brain stem plays a role in metabolic control of estrous cycles in Syrian hamsters. Brain Res 1994; 661: 70-74.

9 Gulyas J, Rivier C, Perrin M, Koerber SC, Sutton S, Corrigan A, Lahrichi SL, Craig AG, Vale W, Rivier J. Potent, structurally constrained agonists and competitive antagonists of corticotropin-releasing factor. Proc Natl Acad Sci USA 1995; 92: 10575-10579.

10 Nappi RE, Bonneau M-J, S. R. Influence of the estrous cycle on c-fos and $\mathrm{CRH}$ gene transcription in the brain of endotoxin-challenged female rats. Neuroendocrinology 1997; 65: 29-46.

11 Viau V, Meaney MJ. Variations in the hypothalamic-pituitary-adrenal 
response to stress during the estrous cycle in the rat. Endocrinology 1991; 129: $2503-2511$.

12 Rivest S, Plotsky PM, Rivier C. CRF alters the infundibular LHRH secretory system from the medial proptic area of female rats: possible involvement of opioid receptors. Neuroendocrinology 1993; 57: 236-246.

13 Petraglia F, Vale W, Rivier C. Opioids act centrally to modulate stressinduced decrease in luteinizing hormone in the rat. Endocrinology 1986; 119: $2445-2450$

14 Petraglia F, Locatelli V, Penalva A, Cocchi D, Genazzani AR, Müller EE. Gonadal steroid modulation of naloxone-induced LH secretion in the rat. J Endocrinol 1984; 101: 33-39.

15 Bhanot R, Wilkinson M. Opiatergic control of LH secretion is eliminated by gonadectomy. Endocrinology 1983; 112: 399-401.

16 Cover PO, Laycock JF, Gartside IB, Buckingham JC. A role for vasopression in the stress-induced inhibition of gonadotrophin secretion: studies in the Brattleboro rat. J Neuroendocrinol 1991; 3: 413-417.

17 Patchev VK, Kalogeras KT, Zelazowski P, Wilder RL, Chrousos GP Increased plasma concentrations, hypothalamic content, and in vitro release of arginine vasopressin in inflammatory disease-prone, hypothalamic corticotropin-releasing hormone-deficient Lewis rats. Endocrinology 1992; 131: 1453-1457.

18 Gillies GE, Linton EA, Lowry PJ. Corticotropin releasing activity of the new CRF is potentiated several times by vasopressin. Nature 1982; 299: $355-357$.

19 Cagampang FRA, Maeda K-I, Tsukamura H, Ohkura S, Ota K. Involvement of ovarian steroids and endogenous opioids in the fastinginduced suppression of pulsatile LH release in ovariectomized rats. J Endocrinol 1991; 129: 321-328.

20 Paxinos G, Watson C. The Rat Brain in Stereotaxic Coordinates, 2nd edn. Sydney: Academic Press, 1986.

21 Merriam GR, Wachter KW. Algorithms for the study of episodic hormone secretion. Am J Physiol 1982; 243: E310-E318.

22 Maeda K-I, Tsukamura H, Uchida E, Ohkura N, Ohkura S, Yokoyama A. Changes in the pulsatile secretion of LH after the removal of and subsequent resuckling by pups in ovariectomized lactating rats. J Endocrinol 1989; 121: 277-283. 